Mediterranean Seaweeds. I. Fucophyceae (Warming 1884). Bot. Mar. 35: 109-130.

SCHIFFNER, V.V. -1931- Neue und bemerkenswerte Meeresalgen. Hedwigia LXXI: 139-205.

Aceptado para su publicación en octubre de 2004
Dirección de los autores. C. PENA MARTÍN \& M. B. CRESPO: CIBIO (Instituto Universitario de la Biodiversidad), Universidad de Alicante, Apdo. 99, 03080 Alicante, España, <carolina.pena@ua.es>; A. GÓMEZ GARRETA: Laboratori de Botànica, Facultat de Farmàcia, Universitat de Barcelona, Av. Joan XXIII s/n, 08028 Barcelona, España.

\title{
136. NOTES ON THE OCCURRENCE OF HYPNELLA PALLESCENS (HOOK.) A. JAEGER (BRYOPHYTA, PILOTRICHACEAE) IN BAHIA, BRAZIL
}

\author{
Silvana B. VILAS BÔAS-BASTOS \& Cid José P. BASTOS
}

Notas sobre la ocurrencia del Hypnella pallecens (Hook.) A. Jaeger (Bryophyta, Pilotrichaceae) en la Bahia, Brasil.

Key words. Pilotrichaceae, Hypnella pallescens, Phyllodon truncatulus, Atlantic Rain Forest, Brazil, Bahia.

Palabras-clave. Pilotrichaceae, Hypnella pallescens, Phyllodon truncatulus, Mata Atlântica, Brasil, Bahia.

The genus Hypnella (C. Muell.) A. Jaeger includes pleurocarpous mosses of neotropical distribution, and according to Buck (1998) is distinguished from other Hookeriales in the seriate papillae over the lumina of the cells. This genus was removed from Hookeriales and placed within the Hypnales, in the Sematophyllaceae, by Crosby (1974), based on supposed relationships to Taxithelium and Glossadelphus. However, Buck (1998) stated that some characteristics, such as strong double costa, lack of differentiated alar cells, 2-celled axillary hairs, and mitrate calyptrae, among other characters, prove to be
Hookeriales more than Hypnales. Thus, the genus Hypnella is positioned within Hookeriales, in the Pilotrichaceae (according to Buck 1998).

Hypnella pallescens (Hook.) A. Jaeger was reported for Brazil by Spruce (1867), Mitten (1869), Crosby et al. (1985), Lisboa \& Yano (1987) and Churchill (1998). This species was erroneously recorded for the state of Bahia by Vilas Bôas-Bastos \& Bastos (2000) as Phyllodon truncatulus (Müll. Hal.) Buck; both species are vegetatively similar, differing only in some characters, mainly to the sporophyte. Studying materials from new collections made in Bahia, this species was 


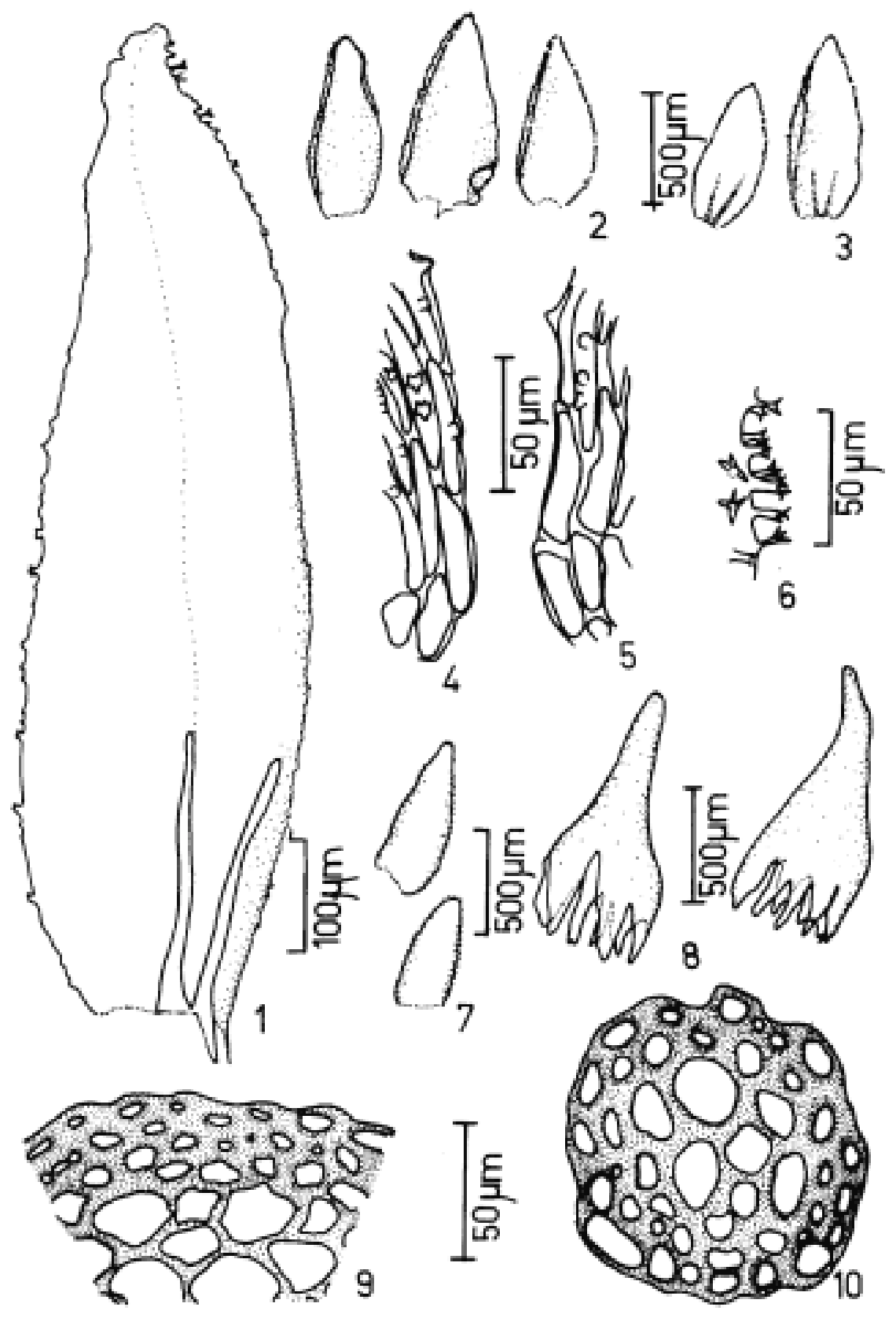

Figures 1-10. Hypnella pallescens (Hook) Jaeg. 1: Leaf, showing the double costa; 2: stem leaves; 3: branch leaves; 4: basal margin of the stem leaf; 5 : basal margin of the branch leaf; 6 : papillae, lateral view; 7: perichaetial leaves; 8: calyptrae; 9: cross section of the stem; 10: cross section of the branch. 
found with sporophytes.

In this present paper, a description and illustrations of some morphological characters (see Buck 1998 and Vilas BôasBastos \& Bastos 2000 for the most complete illustrations) are provided.

The specimens were found at the "Estação Veracruz", a private biological reserve that represents a Tropical Atlantic Rainforest fragment, situated in southern Bahia, Brazil. All specimens are deposited at Alexandre Leal Costa Herbarium (ALCB), of the Instituto de Biologia of the Universidade Federal da Bahia, Brazil.

\section{Hypnella pallescens (Hook.) A. Jaeger Ber.}

Tätigk. St. Gallischen Naturwiss. Ges. 1875-76: 365. 1877. Figs. 1-10.

Basionym:'Hookeria pallescens Hook., Musci Exot. 1: 38. 1818.

Type-locality: Venezuela. Ad ripam fluminis Orinoco prope Esmeraldam, locis opacis Humboldt et Banpland. Holotype: E; Isotypes: BM, NY.

Gametophyte green, closely-foliate, prostrate, branches ascending. Stem in cross section, with 1-2 rows of small thick-walled cells surrounding 4-10 larger cells. Leaves erect-spreading, ovate to ovate-lanceolate, concave; costa short and double, absent in branch leaves; apex broadly obtuse to acute, margins plane, entire to slightly dentate below, strongly serrate above due to projecting large papillae; alar region scarcely or not differentiated, of 1-2 hyaline cells; cells brownish across insertion; median cells fusiform, seriately papillae, papillae large, branched, stalked, stellate; basal cells elongate, rectangular, with 1-4 papillae or smooth. Perichaetial leaves small, ovatelanceolate, strongly papillose. Sporophyte with setae elongate, capsule young, calyptrae mitrate, lobed at base.

Specimens examined: Brazil, Bahia: between Eunápolis e Porto Seguro towns, "Veracruz" Forest Reserve, Juerana trail, 12/ 6/1999, S.B. Vilas Bôas-Bastos \& C. Bastos 1094, 1099 (ALCB).

Geographic Distribution: Cuba, Jamaica, Puerto Rico, Guadeloupe, Dominica, Martinique, St. Lucia, Panama, Colombia, Venezuela, Trinidad, Guyana, Brazil, Ecuador, Peru (Crosby et al. 1985; Buck 1998).

The specimens were found on decaying $\log$ s in ombrophilous forest in southern Bahia. Hypnella pallescens has previously been reported for Brazil only from Amazonas (Spruce 1867, as Hylotapsis; Mitten 1869, as Hookeria; Crosby et al. 1985, Lisboa \& Yano 1987, as Hypnella cymbifolia; Churchill 1998), Pará (Churchill 1998) and Rio de Janeiro (Crosby et al. 1985). In our previous paper (Vilas Bôas-Bastos \& Bastos 2000) this species was erroneously recorded as Phyllodon truncatulus (Müll. Hal.) Buck; both Phyllodon truncatulus and Hypnella pallescens are vegetatively similar species, but the former does not have stalked-stellate papillae, and the calyptra is cucullate. Thus, the records of Phyllodon truncatulus must be excluded from the bryophyte flora from state of Bahia, Brazil.

ACKNOWLEDGMENTS. The authors are grateful to the Veracel Celulose S.A. for promoting access to the area and for support to the collectors.

\section{REFERENCES}

BUCK, W.R. -1998- Pleurocarpous mosses of the West Indies. Mem. of the New York Bot. Garden 82: 1-400.

CHURCHILL, S.P. -1998- Catalog of Amazonian mosses. J. Hattori Bot. Lab. 85: 191-238.

CROSBY, M.B. -1974- Toward a revised classification of Hookeriaceae (Musci). $J$. Hattori Bot. Lab. 38: 129-141. 
CROSBY, M.B., B.H. ALLEN \& R.E. MAGILL -1985-A review of the moss genus Hypnella. The Bryologist 88(2): 121-129.

LISBOA, R.C.L. \& O. YANO -1987- Novas ocorrências de briófitas na Amazônia brasileira. Bol. Mus. Par. Emílio Goeldi, sér. Bot. 3(2): 141-156.

MITTEN, W. -1869- Musci autro-amaricani. Enumeratio muscorum omnium austroamericanorum hucusque cognitorum. Journ. Linn. Soc. London Bot. 12: 1-659.

SPRUCE, R. -1867-Catalogus muscorum fere omnium quos in terris Amazonicus et Andinis per annis 1849-1960, London.
VILAS BÔAS-BASTOS, S.B. \& C.J.P. BASTOS -2000- New occurrence of pleurocarpous mosses for the state of Bahia, Brazil. Trop. Bryol. 18: 65-73.

Aceptado para su publicación en septiembre de 2004

Dirección de los autores. Universidade Federal da Bahia. Instituto de Biologia. Departamento de Botânica. Laboratório de Taxonomia de Algas e Briófitas. Campus de Ondina. 40170-280 Salvador - Bahia - Brazil.

\title{
137. NUEVOS DATOS SOBRE LA PTERIDOFLORA ALÓCTONA IBÉRICA
}

\author{
Juan J. HERRERO-BORGOÑÓN
}

New data about the non-native iberian pterydophyte flora.

Palabras clave. Pteridoflora, Corología, Cyrtomium falcatum, Nephrolepis cordifolia, Valencia, Comunidad Valenciana.

Key words. Pterydophyte flora, Chorology, Cyrtomium falcatum, Nephrolepis cordifolia, Valencia, Valencian Community.

Se aportan nuevos datos que amplían la distribución conocida en la Península Ibérica de dos especies de helechos de distribución tropical, de los que hasta el momento se conocen pocas citas en la misma. Ambos se cultivan con fines ornamentales y presentan una buena capacidad de propagación, habiéndose constatado su naturalización tanto en Europa como en otras partes del mundo.
Cyrtomium falcatum (L. fil.) C. Presl VALENCIA: Valencia, Puente de la Trinidad, 30SYJ2673, 13 m, 16-X-2002, naturalizado, J. J. Herrero-Borgoñón \& I. Vidal, VAL 144932; Id., Puente de Serranos, 30SYJ2573, 13 m, 17-V-2004, naturalizado, I. Vidal \& J.J. Herrero-Borgoñón, VAL 151555 .

La amplia variedad de ambientes en que es capaz de desarrollarse este helecho, 